\title{
THE NATURE OF JARGON IN THE NORMAL AND LANGUAGE IMPAIRED CHILD
}

\author{
DIANE HURWITZ, B.A. (Sp. \& H. THERAPY) (WITWATERSRAND) \\ J.G. Strijdom Hospital, Auckland Park, Johannesburg
}

\section{SUMMARY}

The jargon utterances of two groups of two subjects each, group A, children with normal speech and language development, and group B, children with delayed or impaired speech and language development, were recorded and transcribed. The data were divided into meaningful and non-meaningful categories. The former were analysed into morphemes in terms of distinctive features and phonemes. All subjects were. found to have essentially similar distinctive features, phonemes and morpheme structures with minor exceptions. Int onation varied: group A used more sentence int onation, whereas group B used more word intonation. Word approximations, standard and selflanguage words were found in all subjects. It was concluded that jargon appears to be a fusion of early phonological development and phonetic attempts, and that no significant difference exists between the two groups.

\section{OPSOMMING}

Die brabbeltaal van twee groepe bestaande uit twee proefpersone elk, groepp A, kinders met normale spraak-en taalontwikkeling en groep B, met vertraagde spraak-en taalontwikkeling is opgeneem en neergeskryf. Die gegewens is verdeel in sinvolle en nie-sinvolle kategorië. Eersgenoemde is geanaliseer in morfeme in terme van onderskeidende kenmerke en foneme. Daar is gevind dat al die proefpersone essensiële ooreenstemmende onderskeidende kenmerke het sowel as foneme en morfeme struktuur met klein verskille. Intonasie het verskil. Groep A het meer sinintonasie gebruik terwyl groep B meer woordintonasie gebruik het. Woordapproximasies, standaard woorde, self taalwoorde is gevind in alle proefkonyne. Daar is tot die gevolgtrekking gekom dat brabbeltaal 'n vermenging van vroeër fonologiese ontwikkeling en fonetiese pogings skyn te wees en dat geen betekenisvolle verskil bestaan tussen die twee groepe nie.

Jargon is a type of infant utterance. These and other infant utterances are studied because it is assumed that there exists some correlation between prelanguage and language utterances and that these in some way prepare, determine or establish the bases for later language. Also, their very nature e.g. a paucity or lack of vocalizations, may be used prognostically for later development.

The investigator found the following characteristics or descriptions of jargon in the literature: 
(1) "jargon", "gibberish", "unintelligible jabber" are all acceptable teims 1, 3,4, $6,12,13,15,18$

(2) the earliest age of onset appears to be 3 months, with a peak at 18 months, and is usually gone by 2 years. ${ }^{3,6}, 18,21$

(3) it consists of sounds strung together, usually with repetition of morphemes but also varied sounds. $1,12,18$

(4) characteristically it has adult intonation 1,12 .

(5) it is unintelligble to the listener 5,12

(6) it appears to be non-symbolic. According to Gesell \& Thompson ${ }^{6}$, the

child is communicat ing but Bloom \& Wyatt 21, disagree.

(7) it appears to be voluntary and cont rolled 1,12

(8) not all children use jargon ${ }^{1}$

Van Riper ${ }^{18}$, implies that the jargon of a child with delayed or impaired speech and language development would be similar to the above.

Clinically, some children using jargon have, on further analysis, been found to be using neologisms and/or having multiple articulatory errors and/or with impaired syntax. Jargon must be distinguished from babbling. Myklebust's ${ }^{17}$ definition that babbling is used: ". . . as the pleasureable use of vocalization ..." appears apt. It begins at 3 months and extends to approximately 12 months which is the usual age when the first word is used. Mowrer ${ }^{16}$ suggests that it is used primarily when the infant is contented, and not in the presence of the parent.

\section{EXPERIMENTAL PROCEDURE}

\section{HYPOTHESIS}

(1) The jargon of the child with normal speech and language development is an advanced stage of babbling.

(2) The jargon of the child with delayed or impaired speech and language development will be different to (1)

\section{SUBJEC'TS}

There were two groups of two children each. Group A were children with normal speech and language development. Group B were children with delayed or impaired speech and language development.

Criteria for group A were that the child be between 15 and 19 months, that the intellectual and motor development appeared to be within normal limits (assessed subjectively from observation of child at play) and that the vocalizations were a gibberish with adult intonation. It did not matter if the child used words as well. The subjects were Al, a girl of 17 months, who used only jargon; A2, a girl of 18 months, who used jargon and words.

Criteria for group B were that the child be older than 24 months, that a speech therapist diagnose the utterances as jargon, that intellectual and motor development may or may not be within normal limits. For this group jargon was not defined but obvious and gross articulatory and/or syntax errors were excluded. The subjects were, B1, a girl of 3 years, who used jargon and was at 
the time of testing attending therapy; B2, a boy of 25 months who used jargon which was described by his parents as a "language of his own."

All subjects had English as their home language. Al's parents spoke Hebrew as well, and Bl's parents spoke Hungarian.

These foreign languages could have been an influence on the children and cannot be discounted. However, all the parents insisted that they only spoke English to their children, and that the foreign language was only for private interchange between the parents. Socio-economic status was not considered but it did not appear to vary greatly.

A1, A2 and B1 were all first children of the family. B2 was the third child.

\section{TESITING}

A recording of the spontaneous utterances of each child was taken. The investigator visited each child at least once, so as to familiarise the child with herself and the taperecorder. The recordings were taken on one subsequent visit (except for A2, were recordings were taken over two visits). A Sony portable/mains cassette taperecorder with an Electret condenser microphone was used. The child was recorded in her bedroom whilst playing with toys and books provided by the investigator plus any other toys of her own. On most occasions the mother (or a sibling in the case of $\mathrm{B} 2$ ) was present at the recordings. The child played either with the mother or investigator.

No attempt was made to correlate ut terances with actions.

If certain utterances appeared to have a target word or meaning, this was noted.

The first 20-30 minutes of each recording for Al, B1 and B2 were transcribed. For A2, her jargon ut terances, plus about fifteen minutes of words were transcribed.

The data were transcribed using a Canon Repeat-corder in broad phonetic notation using the symbols of the International Phonetic Alphabet, modified by the investigator with the help of Professor L.W. Lanham, Department of Phonetics and Linguistics, University of the Witwatersrand, Johannesburg. The units of analysis were not phones i.e. speech sounds but phonemes, interpreted in terms of the investigator's English phonemic system.

The symbols used were 'cover symbols' i.e. they stood for any sound that appeared to approximate that symbol eg $/ B /\left[b, b, b^{h}, p, p^{h}\right]$. The symbol includes both voiced and voiceless cognates as one is unable to ascertain voicing without spectrographic analysis.

The cover symbols used: Stops: /B/[b,b, $\left.b^{h}, p, p^{h}\right] ; D /\left[d, d, d^{h}, t, t^{h}\right] ; / G /\left[g, g, g^{h}\right.$ $\left.\mathrm{k}, \mathrm{k}^{\mathrm{n}}\right]$; fricatives: $/ \mathrm{F} /[\hat{\mathrm{f}}, \mathrm{v}] ; / \mathrm{S} /[\mathrm{s}, \mathrm{z}, \mathrm{x}] ; / \stackrel{\mathrm{S}}{\mathrm{S}} /[\stackrel{\mathrm{v}}{\mathrm{s}}, \mathrm{z}]$; nasal resonants: $/ \mathrm{M} /[\mathrm{m}, \underline{\mathrm{l}}]$; $/ N /[n, n, n]$; lateral resonants: $/ L /[1,1]$; any type of flag, trill or central resonant $/ \mathrm{R} /$; semivowels: $/ \mathrm{W} / ; \mathrm{Y} / ; / \mathrm{H} /$ no affricates were used. Consonant clusters were transcribed as consecutive consonants. 
The cover symbols for the vowels:

$\begin{array}{ll}\text { i } & 3 \wedge \\ \text { e } & \partial \\ \text { E } & \alpha\end{array}$

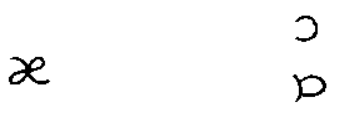

That is, four front vowels; high raised mid, lowered mid, and low; four central vowels: two mid; one low, and one central but rather back, three back vowels; high, mid and low. All front vowels were unrounded and all back vowels rounded. There were three glides $a_{1} i, a_{i} u, i$ Length was not considered. The boundaries of the utterances were difficult to define and was done subjectively. A pause, period of silence or an interruption by another speaker indicated a boundary. Pause and stress were used to determine smaller units within the longer utterances.

The transcriptions were transcribed twice, with an interval of two weeks, by the investigator. Agreement was found.

\section{ANALYSIS OF THE RESULTS}

The data were divided into three categories using intonation as the distinguishing factor: (1) clear, distinct ut terances. (2) Vague utterances eg. musings, wailings, singing. (3) exclamations and interjections.

Categories 2 and 3 were discarded and category 1 was sub-divided: certian shorter sequences appeared to be maximally stressed within a longer utterance and bounded on either side by silence, however minimal the period. These were called morphemes after the definition by Gleason ${ }^{7}$. This term was chosen in preference to word which implies a sound-symbol relationship. A morpheme was composed of any number of syllables which was usually a consonant followed by a vowel; very rarely a vowel occurred in isolation as a syllable, but then it was always followed by a consonant and a vowel. Each consonant and vowel was a phoneme as discribed by Jakobson 11 : "a bundle" of distinctive features i.e. those features that establish contrast between phonemes.

Certain of the morphemes could be recognized as "babytalk" or standard English words and were called such, and included in the data for analysis. This approach was adopted because Lanham ${ }^{14}$ feels that morphemes are phonetic attempts by the child to achieve a target word which would then be stressed.

Bloom ${ }^{1}$ postulates that the child during the jargon period is practising adult intonation. Thus, as an adult would stress an important word, so the child stresses the meaningful morphemes. It is felt, and Gruber ${ }^{9}$ supports this, that the child appears to be speaking language as opposed to babbling and he' found that the morphemes corresponded to those of English. Subjectively, the fact that all children already used recognizable words and that they demanded attention and responses from their listeners gives support for this approach.

If, as it is postulated, the child is attempting to convey meaning then he will be setting up oppositions in the form of a system i.e. distinctive features. Jakobson's 10,11 distinctive features were modified by the investigator on the suggestion of Lanham ${ }^{14}$. Only articulatory features i.e. of place and manner 
were considered. They are as follows: each is binary, either a phoneme has that feature $(+)$ or it does not $(-)$.

(1) Vocalic/ non-vocalic: where there is no obstruction of the airflow by the organs of articulation.

(2) Consonantal/non-consonantal: either complete or incomplete obstruction.

(3) Continuous / non-continuous: partial obstruction.

(4) Resonant / non-resonant: no friction and partial obstruction.

(5) Nasalized / non-nasalized: air flows through the nose, obstruction in the mouth.

(6) Lateral / non-lateral: air flows over the sides of the tongue.

(7) Front / non-front: sound is formed at the front of the mouth.

(8) Back / non-back: sound is formed at the back of the mouth.

(9) Low / non-low: the tongue is low in the mouth.

(10) Glide / non-glide: first vowel is followed by a movement toward another vowel.

Voicing was not recognized as a phonetic feature and thus is not included as a distinctive feature.

The distinctive features are organized into phonemes as follows:

/B/

$$
\left[\begin{array}{l}
+ \text { consonantal } \\
- \text { vocalic } \\
- \text { continuous } \\
+ \text { front }
\end{array}\right]
$$

$\mid \mathrm{F} /$

$$
\left[\begin{array}{l}
+ \text { consonantal } \\
- \text { vocalic } \\
+ \text { continuous } \\
- \text { resonant } \\
+ \text { front }
\end{array}\right]
$$

/M/

$$
\left[\begin{array}{l}
+ \text { consonantail } \\
- \text { vocalic } \\
+ \text { continuous } \\
+ \text { resonant } \\
+ \text { nasalized } \\
+ \text { front }
\end{array}\right]
$$

/D/

$$
\left[\begin{array}{l}
+ \text { consonantal } \\
- \text { vocalic } \\
- \text { continuous } \\
- \text { front }
\end{array}\right]
$$

/S/ incld. $\breve{S}$

$$
\left[\begin{array}{l}
+ \text { consonantal } \\
+ \text { vocalic } \\
- \text { continuous } \\
- \text { front } \\
- \text { back }
\end{array}\right]
$$

$$
\text { iG/ }
$$

$$
\begin{aligned}
& + \text { consonanta } \\
& \text { - vocalic } \\
& \text { - continuous } \\
& + \text { back }
\end{aligned}
$$




\section{$/ \mathrm{L} /$}

$\left[\begin{array}{l}+ \text { consonantal } \\ \text { - vocalic } \\ + \text { continuous } \\ + \text { resonant } \\ \text { - nasalized } \\ + \text { latcral } \\ \text { - front } \\ \text { - back }\end{array}\right]$

$\mid W /$

$$
\left[\begin{array}{l}
+ \text { consonantai } \\
+ \text { vocalic } \\
+ \text { continuous } \\
- \text { resonant } \\
- \text { front }
\end{array}\right]
$$

$/ / /[i, e, E, 3, \partial]$

$\left[\begin{array}{l}- \text { consonantaI } \\ + \text { vocalic } \\ + \text { front } \\ - \text { low }\end{array}\right]$
$/ \mathrm{R} /$

$\left[\begin{array}{l}\text { + consonantaI } \\ \text { - vocalic } \\ \text { + continuous } \\ \text { + resonant } \\ \text { - nasalized } \\ \text { - lateral } \\ \text { - front } \\ \text { - back }\end{array}\right]$

$/ \mathrm{Y} /$

$/ \mathrm{H} /$

$\left[\begin{array}{l}+ \text { consonanta } \\ + \text { vocalic } \\ + \text { continuous } \\ - \text { resonant } \\ - \text { front }\end{array}\right]$

$\left[\begin{array}{l}+ \text { consonantal } \\ + \text { vocalic } \\ + \text { continuous } \\ - \text { resonant } \\ + \text { back }\end{array}\right]$

$/ \mathrm{U} /[\mathrm{u}, \mathrm{\supset}, \mathrm{n}]$

$\left[\begin{array}{l}\text { - consonanta }] \\ + \text { vocalic } \\ + \text { back } \\ - \text { low }\end{array}\right]$

$$
\begin{gathered}
\quad\left[\mathrm{A} /\left[æ_{\mathrm{a}, \mathrm{b}}\right]\right. \\
{\left[\begin{array}{l}
\text { - consonanta }] \\
\text { + vocalic } \\
\text { - front } \\
\text { - back } \\
\text { + low }
\end{array}\right]}
\end{gathered}
$$

The data were re-written in terms of the phonemic system.

\section{RESULTS AND DISCUSSION}

\section{MORPHEME STRUCTURE}

The four most common morpheme structures were: $\mathrm{CV}, \mathrm{CVC}, \mathrm{CVCV}, \mathrm{VCV}$ where the vowel (V) and the consonant (C) may or may not be identical with the morpheme.

In group $\mathrm{A} C \mathrm{CVV}$ appeared to be the most common form, closely followed by $\mathrm{CVC}$; whereas for group $\mathrm{B}, \mathrm{CV}$ was clearly the most common form; $\mathrm{CVC}$ and 
CVCV occurred less often, but more or less equally. VCV was used in. frequently by $\Lambda 2, B 1$ and $B 2$ and not at all by $\Lambda 1$.

All subjects excluding $B 2$ had an additional idiosyncratic structure: A1 was $\mathrm{CV}^{\mathrm{L}}$ : where either $/ \mathrm{L} /$ can bc regarded an established phoneme, thus $\mathrm{CVC}$, or as a phonetic realisation of the vowel, thus $\mathrm{CV}$. Neither can be stated em. phatically. $\Lambda$ similar case occurred with $\mathrm{B} 1$ and $\mathrm{CV}^{\mathrm{n}}$. .

$\Lambda .2$ used CCV: either $C_{1} C_{2} V$ or CC can be recognized as a single element and $\mathrm{C}_{2}$ is listed as a distinctive feature of $C_{1}$. In this manner a new morpheme category does not have to be created. This notation can be used to simplify other morphemes used by B 1 eg VCC VC; CVCC CVC, and others.

Only certain consonants appeared as $\mathrm{C}_{2}$ so that it appears that this explanation is better than postulating the existence of clusters. If $\mathrm{B} 1 \mathrm{did}$ in fact have consonant clusters then it would be cvidence of his abnormal development.

Burlings ${ }^{2}$, Velten ${ }^{19}$, and Winitz \& Irwin ${ }^{20}$ found similar morpheme structures for the period 16-21 months.

\section{DISTINCTIVE FEATURES, PHONEMES AND PHONEMIC SYSTEMS}

The following distinctive features were strongly established in all subjects: [ \pm vocalic], [ \pm consonantal], [ \pm continuous], [ \pm resonant], [ \pm front $],[ \pm$ back], [ \pm low $],[+$ nasal $],[-$ glide $]$. The following are weakly or in the process of being established: [- nasal], [+ lateral], [+ glide]. Only B1 used [- lateral] and it appears to be weakly established. The phonemic system common to all subjects was the following:

$\begin{array}{ccc}\text { Consonants: } & / \mathrm{D} / & / \mathrm{G} / \\ & / \mathrm{S} / & \\ & / \mathrm{N} / \\ & / \mathrm{L} / & \\ & & \end{array}$

Vowels

/I)

(U)

\section{/A/}

The strongest opposition was that of the consonants and vowels. This is the first opposition that the child learns. ${ }^{10,11}$. $A$ ll subjects showed strong opposition between non-continuants (i.e. stops) and continuants (i.e. fricatives and rcsonants). Stops were the predominant type of consonant, and the only type to contrast in three places of articulation.

For 3 subjects (excluding B2) nasal resonants seemed better established than fricatives because they contrasted both labially and dentally. B. 2 used only a dental nasal: this violates Jakobson's Law of Solidarity which states that one cannot have a $[-$ front $]$ before $a[+$ front $]$ consonant. The reasons for this may be that the data were insufficient, inaccuracy of transcription or impairment of development.

Because fricatives occurred so rarely, and particularly labial fricatives it seems that the principle of "underarticulation" may be applied i.e. the child is aiming at a stop but produces a fricative. 
The results appear to be in agreement with Jakobson ${ }^{10,11}$ who states that the first opposition among type is stop vs. nasal, and not Velten ${ }^{19}$ who states that it is stop vs. fricative. The acquisition of non-nasal resonants is a late acquisition: all subjects used /L/ infrequently. B1 used both /R/ and /L/ and this is usually an extremely late acquisition and is probably further evidence of his impaired development.

All subjects used $/ \mathrm{W} /$ and this agrees with previous findings ${ }^{10,19}$ which indicate that it is the first semi-vowel to emerge. Only Al did not use /Y/ and this is probably because she was younger and at an earlier stage of development. $/ \mathrm{H} /$ is difficult to transcribe and may have been confused with a voiceless vowel. B1 used it once, B2 more frequently. Its absence in Group A may be queried as Velten ${ }^{19}$ found it established at 16 months.

The many varied phonetic realizations of the vowels were fitted into Jakobson's ${ }^{10,11}$ primary triangle:

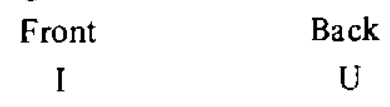

A

Low

The status of the vowels is difficult to ascertain, but if one assumes that vowel and consonant development run concurrently then it would appear that the oppositions do exist. However, Goldstein ${ }^{8}$ states that at a certain period only the $C$ is contrastive, this may be so in view of the word approximations.

[+ glide] is weakly established: two glides were used by all subjects. Burlings ${ }^{2}$ reported that his child used them at 18-19 months.

The results with minor exceptions appear to be confirmed by Jakobson's ${ }^{10,11}$ studies. The distinctive features are similar to those of Joan Velten ${ }^{19}$ at 16 months with the exception that the investigator has set up three place distinctions instead of two.

\section{WORD APPROXIMATIONS}

In.these attempts the child would variously try different vowels and consonants, but each was clearly recognizable eg.

DiDi

DiDa

$\mathrm{BiDi}$

GiDi

$\mathrm{GaGi}$

/GIGI/ [Kiti] Kitty

This seems to be strong support for the postulation that the other morphemes are also some sort of variation of some unknown target word.

\section{WORDS}

These included both standard and self language words: all subjects had them but the number varied: A1 - two, A2 - many, B1 - four, B2 - only self language word eg. nana for mother. 


\section{INTONATION}

Group A used recognizable English sentence intonation, with the occasional question intonation. A2 used word intonation when using words.

Group B used the same type of intonation as group A but to a lesser extent; they tended to give each morpheme separate intonation. Intonation observed in group A confirms similar observations made by Bloom. ${ }^{1}$

\section{CONCLUSION}

Hypothesis 1 is rejected because it seems that the jargon of the child with normal speech and language development appears to be a fusion of the early stages of phonological development and phonetic attempts at a target, possibly occuring either before or simultaneously to the acquisition of the first words i.e. it is postulated that jargon belongs not to the pre-language but to the language period or alternatively represents a bridge between the two. It seems doubt ful though that jargon can be said to be a language.

Hypothesis 2 cannot be accepted nor rejected: the jargon of the two groups appears to be essentially the same; if this is so, then group B may be said simply to have delayed speech. But if the various deviations discussed are accepted as such then one can conclude that group B's development is impaired.

The implications of this study appear to be that if a child is using jargon beyond two years, his speech and language development is delayed but that he does seem to be able to learn oppositions. Thus diagnosis should indicate those contrasts that he has and therapy dire cted towards those he has not. It would seem most appropriate to begin therapy at the holophrastic or twoword stage.

\section{REFERENCES}

1. Bloom, 1. (1970): Language Development: Form and Function in Emerging Grammars. The MIT Press, Cambridge, Massachusetts and London.

2. Burling, R. (1959): Language Development of a Garo and English speaking child. Word, 15, 45-68.

3. Cameron, J., Livson, N., Bayley, N. (1967): Infant Vocalizations and the ir Relationship to Matu re Intelligence. Science, 157, 331-333.

4. Concise Oxford Dictionary, 5th Ed.

5. Day, E.J. (1932): The Development of Language in twins: Comparison of Twins and single children. Child Development. 3, 3, 179.199.

6. Gesell, A.\& Thompson, H. (1934): Infant Behaviour: Its genesis and growth. McGraw.Hill Book Co., Inc. New York \& London.

7. Gleason, H.A. (1961): An Introduction to Descriptive Linguistics. (Revised Edition) Holt, Rinehart \& Winston, lnc. New York.

8. Goldstein, K. (1948): Language and Language Disturbances. Grune \& Stratton, New York.

9. Gruber, J.S. (1973): Playing with Distinctive Features in the Babbling 
of Infants. In Studies of Child Language Development. Ferguson, C.A. \& Slobin, D.I. (Eds.) Holt, Rinehart \& Winston, Inc. New York.

10. Jakobson, R. (1968): Child Language, Aphasia and Phonological Universals. Mouton \& Co., N.V. Publishers, The Hague.

11. Jakobson, R. \& Halle, M. (1956): Fundamentals of Language. Mouton $\&$ Co., 'S- Gravenhage.

12. Jones, M.V. (1972): Language Development: The key to learning. Charles C. Thomas.

13. Komfeld, J.R. (1971): Theoretical Issues in Child Phonology. Paper from the Seventh Regional Meeting of The Chicago Linguistic Society, April 16th-18th. Chicago Linguistic Society, Chicago, Illinois.

14. Lanham, L.W. (1974): Personal Communication.

15. Milisen, R. (1966): Articulatory Problems. Chap. 13 in Speech Pathology. Rieber, R.W. \& Brubaker, R.S. (Eds.). North Holland Publishing Co., Amsterdam.

16. Mowrer, O.H.(1958): Hearing and Speaking: an analysis of language learning. J. Speech. Hear Dis., 23, 143-152.

17. Myklebust, H.R. (1957): Babbling and Echolalia in language Theory. J. Speech Hear. Dis., 22, 3, 356-60.

18. Van Riper, C. (1972): Speech Correction: Principles and methods. (5th Ed.) Constable \& Co., Ltd., London.

19. Velten, H.V. (1943): The Growth of Phonemic and Lexical Patterns in Infant Language. Language, 19, 281-292.

20. Winitz, H. \& Irwin O.C. (1958): Syllabic and Phonetic structure of infants' early words. J. Speech. Hear. Res., 1, 250-256.

21. Wyatt G.L. (1969): Language Learning \& Communication Disorders in Children. Collier - MacMillan, Canada Ltd., Toronto, Ontario. 


\section{BRÜEL \& KJAER}

\section{Manufacturers of Electro-Acoustical Instrumentation}

$\star$ Audiometer calibration

$\star$ Hearing aid test sets

$\star$ Sound level meters

$\star$ Noise dose meters

$\star$ Artificial ears

$\star$ Artificial voice

$\star$ Artificial mastoid

$\star$ Frequency analysers

For more information write or phone:

Sole S.A. Agents:-

Telkor Electronics (Pty.) Ltd.

P.O. Box 7764

Johannesburg 200 Telephone Jhbg.: 836-1301

ALSO:-

Dowson \& Dobson Ltd. +

Durban - Cape Town - Port Elizabeth

+ Member of the Afrox Group. 